\title{
SLIDING WEAR BEHAVIOR OF NIOBIUM CARBIDE COATED AISI 52 IOO BEARING STEEL
}

\author{
Anael Preman Krelling ' \\ Julio César Giubilei Milan ${ }^{2}$ \\ César Edil da Costa ${ }^{2}$ \\ Elisangela Aparecida dos Santos Almeida ${ }^{2}$ \\ Alexandre Galiotto ${ }^{2}$
}

\begin{abstract}
Sliding wear behavior of niobium carbide coated AISI 52100 bearing steel balls against AISI 1045 quenched steel discs was investigated. Thermo-reactive diffusion (TRD) treatment was carried out at $1000^{\circ} \mathrm{C}$ for 4 hours by pack cementation method. NbC phase with II $\mu \mathrm{m}$ in thickness was identified by SEM microscopy and XRD technique. Ball-on-disc wear tests were carried out without lubrication under 2 and ION load at sliding speeds of 0.1 and $0.3 \mathrm{~m} / \mathrm{s}$. A $300 \%$ increase in sliding speed resulted in $24 \%$ and $27 \%$, increasing in friction coefficient of niobium carbide coated AISI 52100 steel balls for $2 \mathrm{~N}$ and ION. Wear resistance of AISI 52100 steel was improved up to 78 times after TRD treatment depending on applied load and sliding velocity. Wear mechanisms are adhesive-oxidative for hardened balls and abrasive-oxidative for coated balls against hardened AISI 1045 steel discs.
\end{abstract}

Keywords: Sliding wear; Steel; Niobium carbide coating; Friction.

\section{INTRODUCTION}

Thermo-reactive deposition/diffusion (TRD) treatment is a method for surface coating steels with a hard and wear-resistant layer of carbides, nitrides, carbonitrides [I] or borides [2] by the diffusion of carbon, nitrogen or boron in the steel substrate into a deposited layer of the carbide-, nitride- or boride-forming element.

The TRD treatment can be performed using salt baths [3,4], fluidized beds [5,6] or pack cementation [7-12] at high temperatures $\left(850-1050^{\circ} \mathrm{C}\right)$ with treatment times of $0.5-10$ hours, resulting in a layer of depth $5-15 \mu \mathrm{m}$.

Pack cementation TRD powder usually consists of a metallic element (carbide-, nitride- or boride-forming); one inert filler that does not take part in the formation reactions of the layers, usually $\mathrm{Al}_{2} \mathrm{O}_{3}$ or $\mathrm{SiC}$; and an activator, for example $\mathrm{NH}_{4} \mathrm{Cl}$ that, when dissociated, chemically binds with the carbide-, nitride- or boride-forming element to form chlorides that will then react with the substrate to generate, for example, carbide layers [12,13].

Niobium carbide can be used in high-temperature environments because it has a high melting point $\left(3873^{\circ} \mathrm{C}\right)[14]$, hardness [15], fracture toughness, Young's modulus [7], wear resistance [16] and corrosion resistance [I].

The wear resistance of $\mathrm{NbC}$ layers has previously been investigated in a number of steel substrates: AISI I040 [17, I8], AISI D2 [3], AISI HI3 [3, I5] and AISI M2 [15]. Niobium carbide layers have proved to be an efficient coating for improvement of the wear resistance of steel substrates. For example, it was found that the niobium carbide layer improved the wear resistance of AISI 1040 steel by up to I000-fold [18]. The niobium carbide layer on AISI HI 3 hot work tool steel demonstrated intermediate wear behavior between a VC coating and a boride coating [3] and better wear resistance than ion nitrided AISI HI3 [15].

The aims of this work are to produce a wear resistant coating of niobium carbide on AISI 52100 steel balls using the pack cementation method and evaluate its tribological behavior. AISI 52100 steel can be used in tools for cold work dies, cold extrusion tools, bearings, etc. Increasing the quality of the tools is only about $5 \%$ of its cost and its preparation time, making it feasible to consider any surface treatment as an investment [19]. Ball-on-disc wear tests were conducted according to ASTM G99-05 standard at sliding speeds of 0.1 and $0.3 \mathrm{~m} / \mathrm{s}$ and under loads of 2 and $10 \mathrm{~N}$.

\section{EXPERIMENTAL PROCEDURE}

AISI 52100 steel balls, $6 \mathrm{~mm}$ in diameter, with a chemical composition of: $0.98-1.1$ wt.\% C, $0.15-0.35$ wt.\% $\mathrm{Si}, 0.25-0.45$ wt.\% Mn and I. $30-1.60 \mathrm{wt} . \% \mathrm{Cr}$, were TRD treated in a solid medium consisting of $\mathrm{Fe}-\mathrm{Nb}, \mathrm{Al}_{2} \mathrm{O}_{3}$ and $\mathrm{NH}_{4} \mathrm{Cl}$ at $1000{ }^{\circ} \mathrm{C}$ for 4 hours. Niobium carbide coating

'Instituto Federal de Santa Catarina - IFSC, Joinville, SC, Brasil. E-mail: anael.krelling@ifsc.edu.br

${ }^{2}$ Universidade do Estado de Santa Catarina - UDESC, Joinville, SC, Brasil.

2I 76-I523/C 2016 Associação Brasileira de Metalurgia, Materiais e Mineração. Published by ABM. This is an open access paper, published under the Creative Commons CC BY-NC-ND license (Attribution-NonCommercial-NoDerivs) - https://creativecommons.org/licenses/ by-nc-nd/4.0/. 
was carried out in an electrical resistance furnace under an argon atmosphere at atmospheric pressure. The hardened AISI 52100 steel balls were also analyzed.

AISI 1045 steel discs, $6 \mathrm{~mm}$ in thickness, were cut from a bar of diameter $25.4 \mathrm{~mm}$. The steel discs were sanded with silicon carbide abrasive paper up to 600 grit and polished with I $\mu$ m alumina suspension. The AISI I 045 plain carbon steel discs usually had a chemical composition of: 0.43-0.48 wt.\% C, 0.60-0.90 wt.\% Mn, 0.15-0.35 wt. \% Si, $0.30-0.40$ wt. \% Cr, $0.02-0.05$ wt. \% Al, 0.025 wt. \% P and $0.02-0.04$ wt.\% S. The discs were water quenched and tempering was not performed.

The roughness of the AISI 52100 steel balls and AISI 1045 steel discs were measured using a Leica DCM 3D confocal microscope. Scanning electron microscopy (SEM) and energy dispersive $\mathrm{X}$-ray spectroscopy (EDS) analysis was performed on the cross-section and wear scars of the balls, and the disc wear tracks using Zeiss DSM-940A and JEOL JSM-670 I F instruments. X-ray diffraction (XRD) analysis of the niobium carbide coatings was performed using $\mathrm{Cu} \mathrm{K}{ }_{\alpha}$ radiation over a $2 \theta$ range of $20-90^{\circ}$ using a Shimadzu 6000 diffractometer. Micro-hardness tests were performed on a Future-Tech FM-800 tester. A $25 \mathrm{~g}$ load was used and the indentation time was $10 \mathrm{~s}$.

Ball-on-disc wear tests were carried out in order to investigate the tribological behavior of coated and uncoated AISI 52 I 00 steel balls sliding against hardened AISI I 045 steel discs for 300, 600 and $900 \mathrm{~m}$ under an applied load of $2 \mathrm{~N}$ and $10 \mathrm{~N}$ at sliding speeds of $0.1 \mathrm{~m} / \mathrm{s}$ and $0.3 \mathrm{~m} / \mathrm{s}$ in room temperature $\left(25^{\circ} \mathrm{C}\right)$. The wear scar diameter of the balls was measured by optical microscopy and the specific wear rate of the balls was calculated according to Equation I [17]:

$$
k_{b}=\frac{\pi d^{4}}{64 R P S}
$$

where $d$ is the wear scar diameter of the worn area of the ball, $R$ is the ball radius, $P$ is the applied load and $S$ is the sliding distance.

\section{RESULTS AND DISCUSSION}

The SEM cross-sectional examinations demonstrated that the niobium carbide layer formed on AISI 52100 bearing steel had a uniform thickness and was firmly bonded to the steel substrate (Figure I).

Two distinct regions could be identified on the cross-section of the niobium carbide coated AISI 52100 steel ball: (I) a niobium carbide layer consisting of $\mathrm{NbC}$,
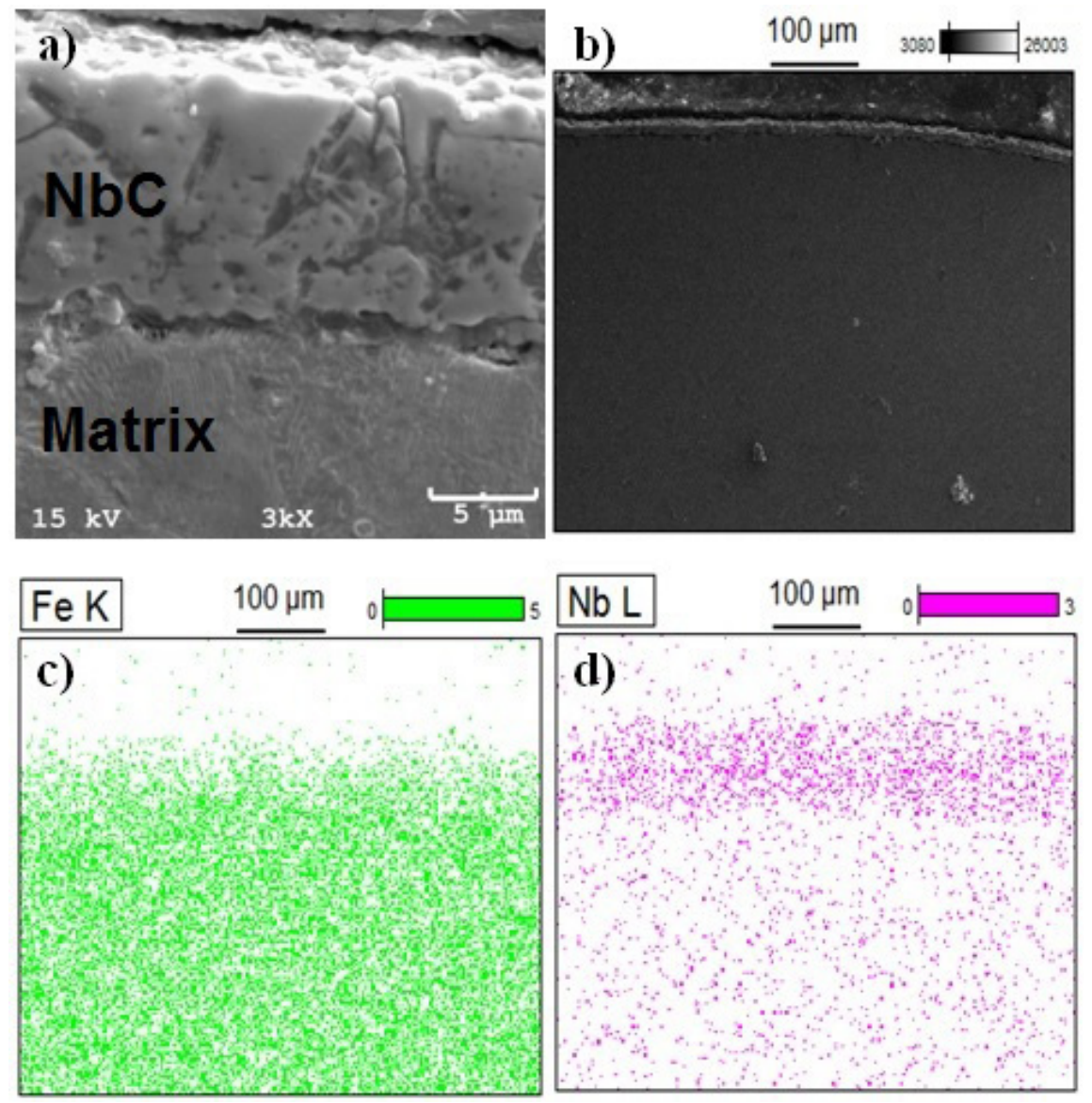

Figure I. SEM micrographs (a, b) and EDS mapping (c, d) of niobium carbide coated AISI 52100 steel balls. 
and (II) a steel matrix. The $\mathrm{NbC}$ formation was confirmed by XRD analysis (Figure 2 ).

The layer thickness was about II $\mu \mathrm{m}$ (Figure Ia). The Vickers micro-hardness was measured at least five times on each region. The hardness of the hardened AISI 1045 steel discs and hardened AISI 52100 steel balls were $570 \pm 9 \mathrm{HV}_{0.025}$ and $822 \pm 14 \mathrm{HV}_{0.025}$, respectively. The hardness of the niobium carbide layer and the matrix of AISI 52100 balls were $2095 \pm 310 \mathrm{HV}_{0.025}$ and $358 \pm 4 \mathrm{I} \mathrm{HV} \mathrm{H}_{0.025}$ respectively. These results are in good agreement with other works $[1,7,17,18]$. The roughness of the AISI 52100 steel balls were measured using a confocal microscopy technique, and the values were $\mathrm{Sa}=1.20 \mu \mathrm{m}$ and $\mathrm{Sa}=2.42 \mu \mathrm{m}$ for the hardened and niobium carbide coated balls, respectively (Figure 3). Hardened AISI 1045 steel discs showed a $\mathrm{Sa}=0.12 \mu \mathrm{m}$ average roughness.

Figure 4 shows the friction coefficient behavior with variation of sliding speed. It is clear from this figure that the friction coefficient increased with increasing sliding speed in the range $0.1-0.3 \mathrm{~m} / \mathrm{s}$. A $300 \%$ increase in sliding speed resulted in $24 \%$ and $27 \%$ increases in the friction coefficients of the niobium carbide coated AISI 52100 steel balls for loads of 2 and $10 \mathrm{~N}$, respectively. These results are in good agreement with Woydt and Mohrbacher [20]. The same increase in sliding speed resulted in $48 \%$ and $25 \%$ increases in the friction coefficients of the hardened AISI 52100 steel balls for the same loads of 2 and $10 \mathrm{~N}$, respectively. The friction coefficients of the hardened and niobium carbide coated balls sliding against hardened AISI 1045 steel discs, with a $2 \mathrm{~N}$ normal load at sliding speeds of $0.1-0.3 \mathrm{~m} / \mathrm{s}$ were in the ranges $0.42-0.62$ and $0.50-0.62$, respectively. For a normal load of $10 \mathrm{~N}$ the friction coefficients were $0.40-0.50$ and $0.45-0.57$ for the hardened and niobium carbide coated balls, respectively. This may be due to the increasing temperature of the wear scar, which causes greater oxidation [ I7]. When niobium carbide coating was formed over AISI 1040 flat end pins sliding against AISI D2

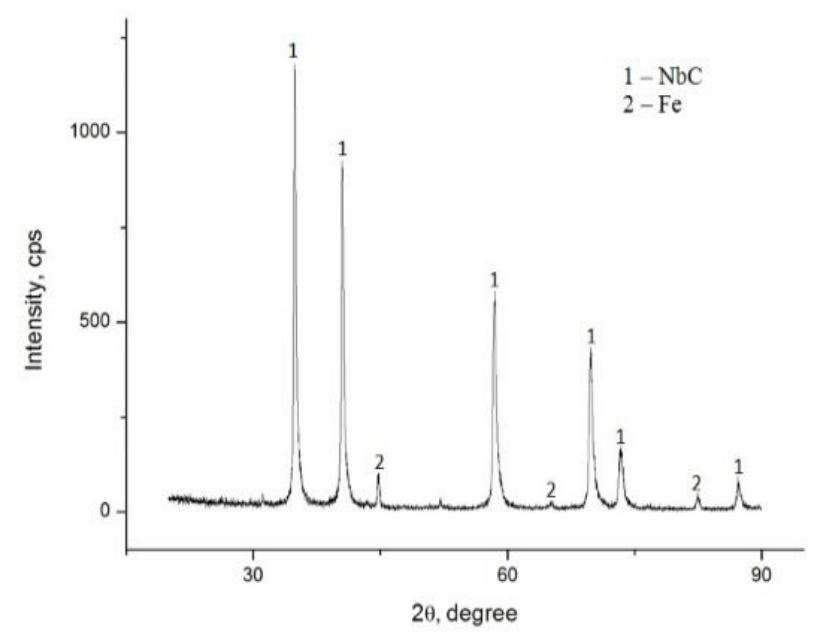

Figure 2. X-ray diffraction pattern of niobium carbide layer formed on AISI 52100 steel substrate. steel discs, the friction coefficient decreased with increasing sliding speed for sliding speed in the range of $0.5-5 \mathrm{~m} / \mathrm{s}$ [ I 8].

The variation in specific wear rate for niobium carbide coated and hardened AISI 52100 steel balls is illustrated in Figure 5. It is clear from this figure that niobium carbide coated balls presented higher wear resistance than hardened balls. At a sliding speed of $0.1 \mathrm{~m} / \mathrm{s}$ the specific wear rate of the hardened AISI 52100 steel balls was up to I 3 times higher than that of the niobium carbide coated balls. For a sliding speed of $0.3 \mathrm{~m} / \mathrm{s}$, the difference in specific wear rate
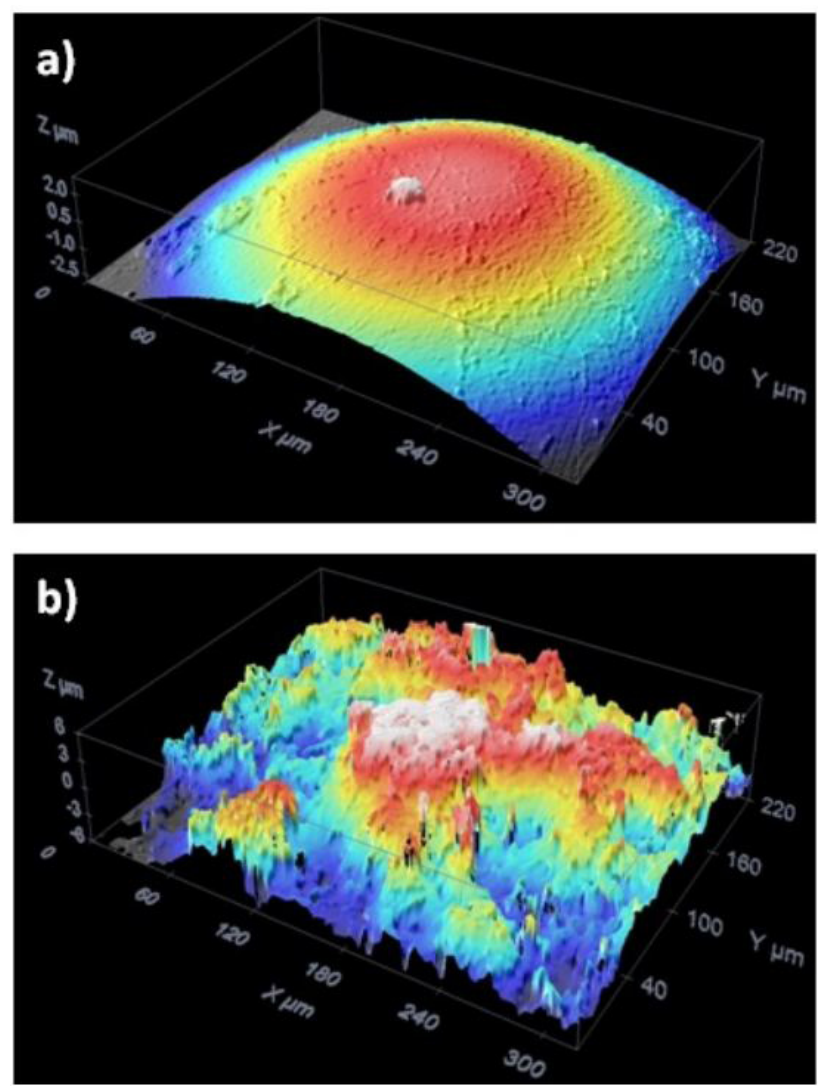

Figure 3. Confocal images of hardened (a) and niobium carbide coated (b) AISI 52100 steel balls.

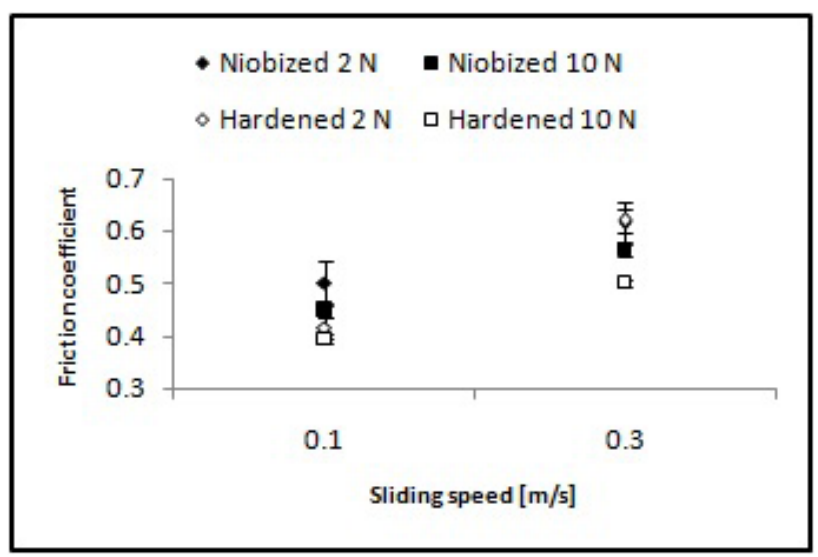

Figure 4. Friction coefficient of hardened and niobium carbide coated balls against hardened AISI 1045 steels disc according to sliding speed. 
was up to 78 times, and was higher for the uncoated steel. The specific wear rates of the hardened and niobium carbide coated balls with $2 \mathrm{~N}$ of normal load at sliding speeds of $0.1-0.3 \mathrm{~m} / \mathrm{s}$ were in the ranges $7.21 \times 10^{-7}-7.31 \times 10^{-7} \mathrm{~mm}^{3} / \mathrm{N} . \mathrm{m}$ and $6.74 \times 10^{-8}-8.55 \times 10^{-9} \mathrm{~mm}^{3} / \mathrm{N} . \mathrm{m}$, respectively. For a normal load of $10 \mathrm{~N}$, the specific wear rates were $3.91 \times 10^{-7}-2.68 \times 10^{-7} \mathrm{~mm}^{3} / \mathrm{N} . \mathrm{m}$ and $2.76 \times 10^{-8}-5.27 \times 10^{-8} \mathrm{~mm}^{3} / \mathrm{N} . \mathrm{m}$ for hardened and niobium carbide coated balls, respectively.

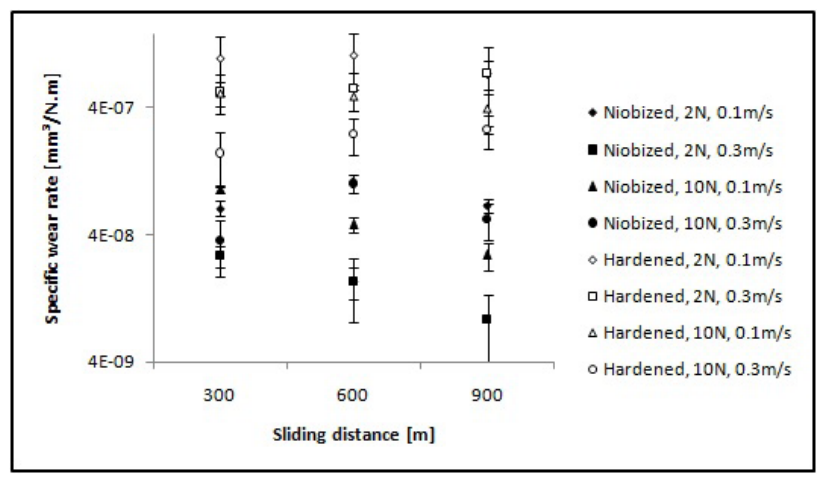

Figure 5. Specific wear rate of hardened and niobium carbide coated balls against hardened AISI 1045 steel disc according to sliding distance.
Table I summarize the results of the specific wear rate of the ball for a sliding distance of $900 \mathrm{~m}$.

Wear tracks and EDS spectra of hardened AISI I 045 steel disc against hardened balls are illustrated in Figure 6. As shown in this figure, there was an increase in the transfer layer (darker spots in Figure 6a and Figure 6b) with increasing load. Furthermore, Figure 6d indicates the presence of $\mathrm{Cr}$ and $\mathrm{Mn}$ on the wear track for hardened AISI 52100 ball sliding against hardened AISI 1045 disc. Chromium and manganese are not alloying elements of the AISI I 045 steel discs so it is reasonable to assume that there was adhesion of the ball material on the wear track of the disc. In addition, the presence of oxygen on Figures $6 \mathrm{c}$ and $6 \mathrm{~d}$ indicate that an oxidative mechanism also occurred on the worn tracks. Thus, the wear mechanisms of the untreated AISI 52100 balls were adhesive and tribo-oxidative wear.

As can be seen in Figure 5 and Table I the results seem to indicate that increasing load leads to a decrease in the specific wear rate, specially for hardened AISI 52100 steel balls. In Figure 6 it is noted that for higher applied loads there was the formation of larger spots of transfer layer. The presence of this transfer layer can change significantly the tribological properties of the counterface [2I]. Therefore,
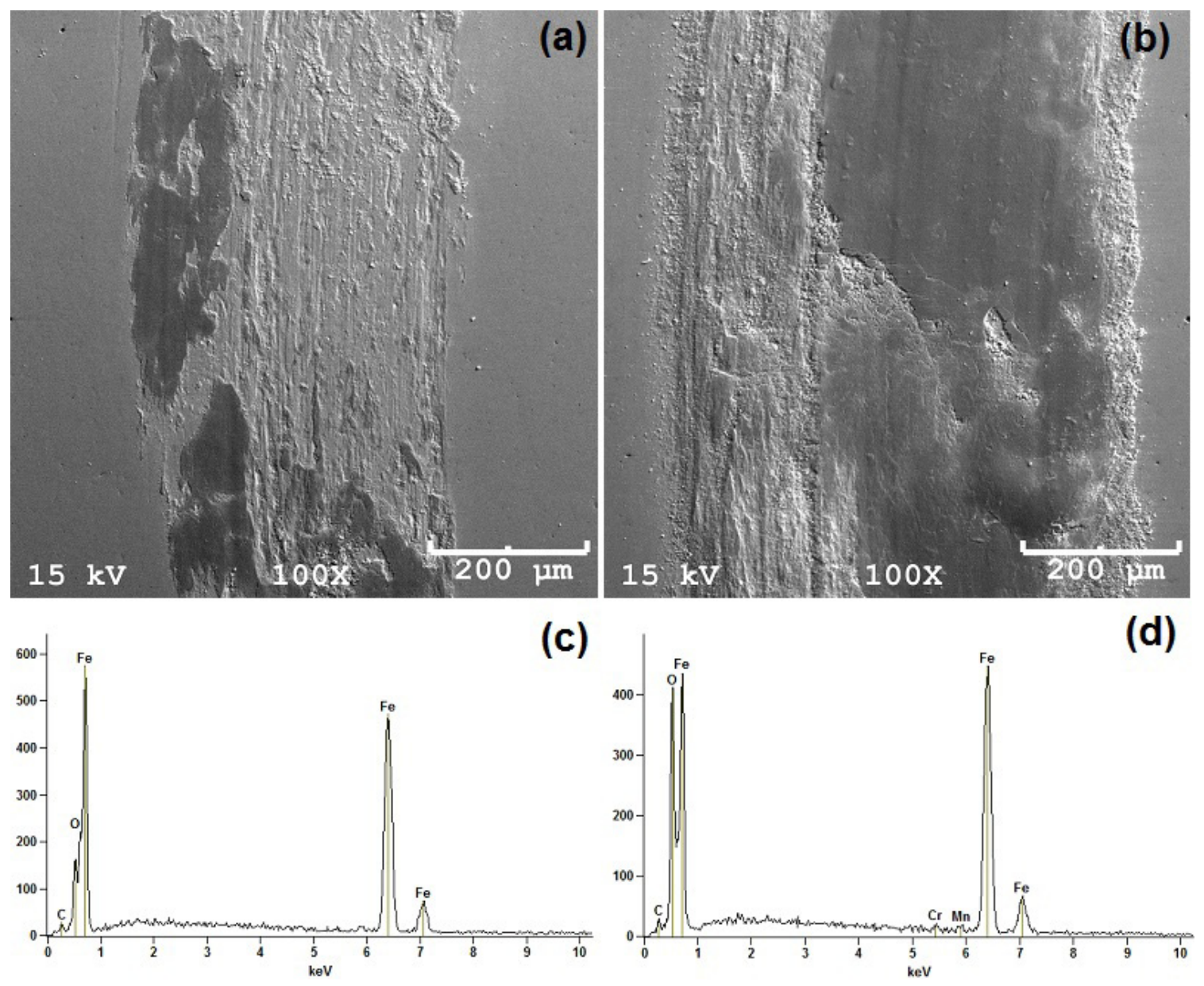

Figure 6. Worn tracks and EDS mapping of AISI 1045 steel discs against hardened AISI 52100 steel balls at $0.1 \mathrm{~m} / \mathrm{s}$. (a, c) $2 \mathrm{~N}$ load, (b, d) I0 N load. Sliding distance of $900 \mathrm{~m}$. 
wear is reduced when the compact wear debris particles layers are formed [22,23]. For shorter distances it was noted that the formation of a protective transfer layer is very limited, being larger when the sliding distance increase, which is in good agreement with other work [24].

For niobium carbide coated AISI 52100 steel balls sliding against hardened AISI 1045 steel discs, an increment in load resulted in deeper grooves on the wear tracks (Figure 7a and Figure 7b). Despite this fact, increasing the load did not result in increasing oxidation on the disc's wear tracks

Table I. Specific wear rate of the ball for a sliding distance of $900 \mathrm{~m}$.

\begin{tabular}{cccc}
\hline Treatment & $\begin{array}{c}\text { Load } \\
{[\mathbf{N}]}\end{array}$ & $\begin{array}{c}\text { Sliding velocity } \\
{[\mathbf{m} / \mathbf{s}]}\end{array}$ & $\begin{array}{c}\mathbf{k}_{\mathbf{b}} \times \mathbf{~ O}^{-8} \\
{\left[\mathbf{m m}^{3} / \mathbf{N m}\right]}\end{array}$ \\
\hline \multirow{4}{*}{ Niobized } & 2 & 0.1 & $6.74 \pm 0.87$ \\
& \multirow{2}{*}{10} & 0.3 & $0.85 \pm 0.53$ \\
& \multirow{4}{*}{ Hardened } & 0.1 & $2.76 \pm 0.66$ \\
& \multirow{2}{*}{10} & 0.3 & $5.27 \pm 4.00$ \\
\hline & & 0.1 & $72.11 \pm 47.34$ \\
& & 0.3 & $73.06 \pm 2.10$ \\
& & 0.3 & $39.08 \pm 3.38$ \\
& & & $26.79 \pm 13.18$ \\
\hline
\end{tabular}

(Figure 7c and Figure 7d). However, for niobium carbide coated balls, it was found that the increment in sliding speed resulted in greater oxidation. Even when performed at room temperature the increasing in sliding speeds led to increasing surface temperature due to frictional heating [25] and then oxidative wear took place [I7,26]. EDS analysis of coated balls after the wear tests confirm that there is an increase of niobium content and a decrease of iron when sliding speed was increased. This suggests a greater formation of niobium oxides than iron oxides. However, when the applied load is increased, there is an increasing in iron content and decreasing of niobium. It is believed that this increment in applied load resulted in delamination of $\mathrm{NbC}$ layer, increasing the content of iron oxide on the wear scar. Thus, the wear mechanisms of the niobium carbide coated AISI 52100 balls were abrasive and tribo-oxidative wear.

In Figure 8, it is clear that the niobium carbide layer of the balls was completely smeared off under the $10 \mathrm{~N}$ load condition and with a $900 \mathrm{~m}$ sliding distance. The carbide layer cracked, and delamination occurred (Figure 9). Hard wear debris acts as abrasive particles, increasing the depth and number of grooves on the wear tracks.
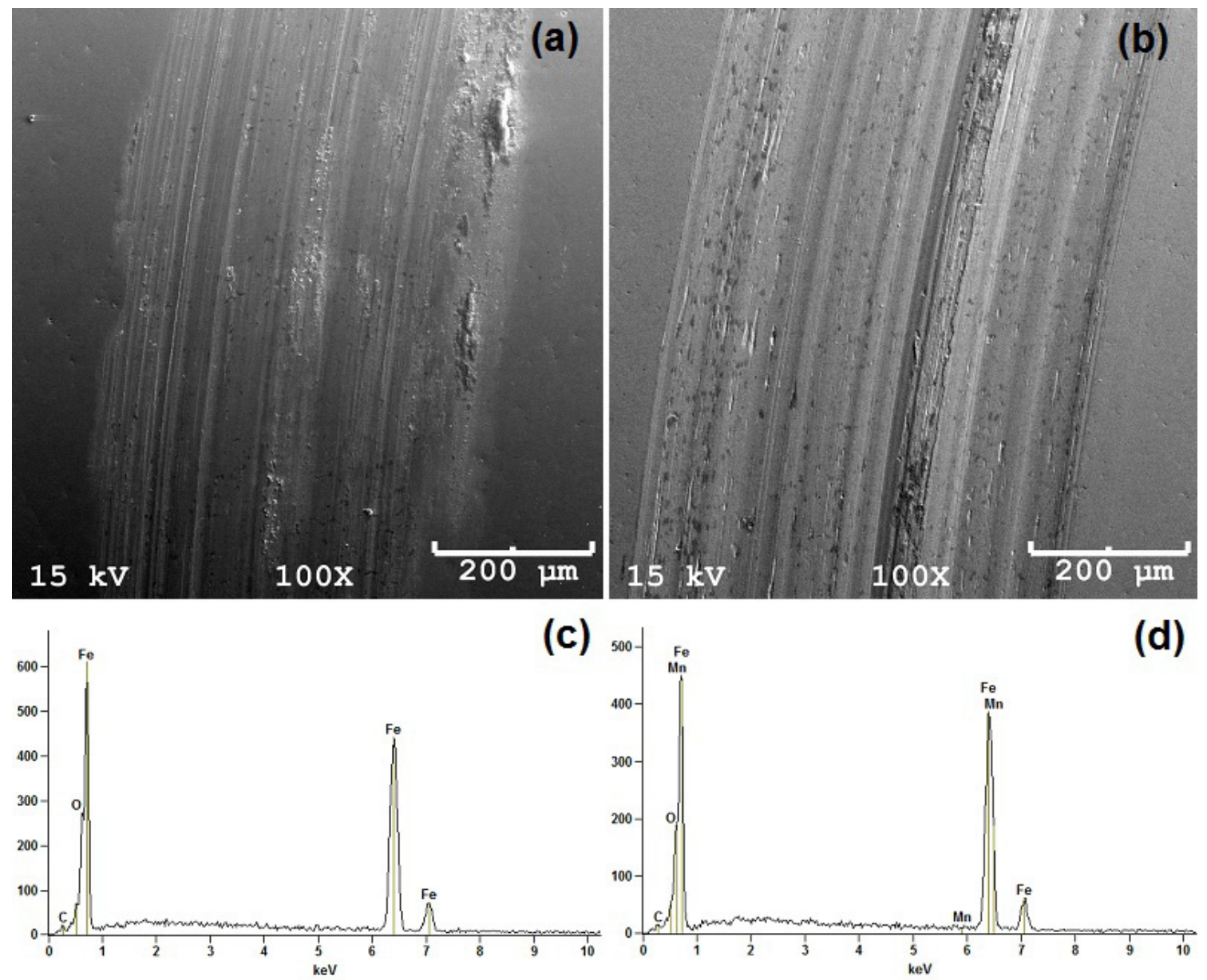

Figure 7. Worn tracks and EDS mapping of niobium carbide coated AISI 52100 steel balls against hardened AISI 1045 steel discs at $0.3 \mathrm{~m} / \mathrm{s}$. (a, c) $2 \mathrm{~N}$ load, (b, d) $10 \mathrm{~N}$ load. Sliding distance of $900 \mathrm{~m}$. 

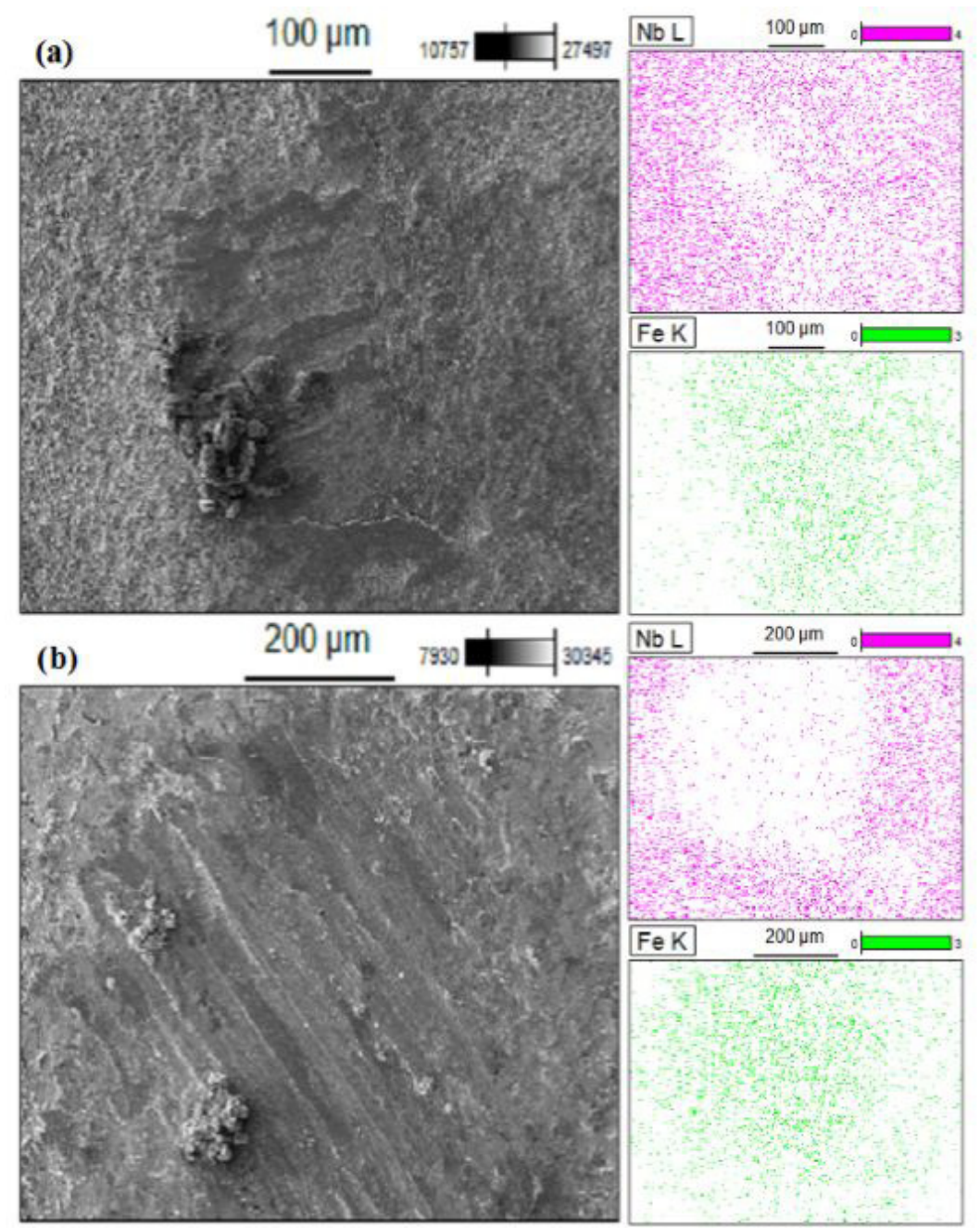

Figure 8. Worn scars and EDS mapping of niobium carbide coated balls (a) $2 \mathrm{~N}$ load and (b) $10 \mathrm{~N}$ load, at sliding speed of $0.1 \mathrm{~m} / \mathrm{s}$ and sliding distance of $900 \mathrm{~m}$.

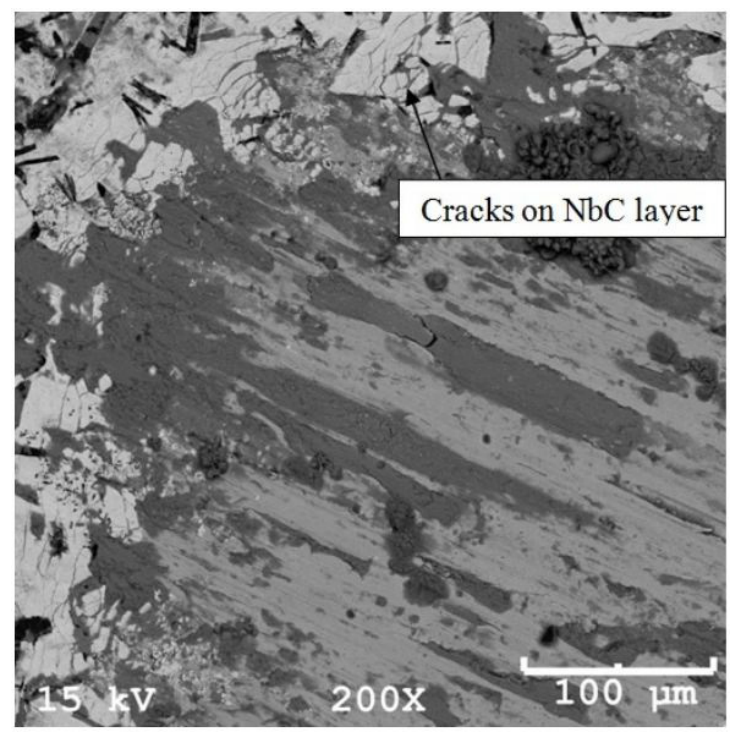

Figure 9. Cracks formed on the worn scar of niobium carbide coated AISI 52100 steel ball $0.1 \mathrm{~m} / \mathrm{s}$ with normal load of $10 \mathrm{~N}$ and sliding distance of $900 \mathrm{~m}$.

\section{CONCLUSIONS}

When the above results are taken into consideration, the following conclusions can be drawn:

(I) A layer of $\mathrm{NbC}$ can be achieved on the surface of AISI 52100 bearing steel balls using the pack cementation method.

(2) The thickness of NbC layer was about II $\mu \mathrm{m}$ and its hardness was $2095 \pm 310 \mathrm{HV}_{0.025}$.

(3) The friction coefficients increased with increasing sliding speed.

(4) The friction coefficients of hardened and niobium carbide coated balls sliding against hardened AISI I 045 steel discs, with $2 \mathrm{~N}$ of normal load at sliding speeds in the range $0.1-0.3 \mathrm{~m} / \mathrm{s}$ were $0.42-0.62$ and $0.50-0.62$, respectively. Fora normal load of $10 \mathrm{~N}$ the friction coefficients were $0.40-0.50$ and $0.45-0.57$, respectively.

(5) The specific wear rate of hardened balls was up to 13 times higher than niobium carbide coated balls at a sliding speed of $0.1 \mathrm{~m} / \mathrm{s}$ and applied load of $10 \mathrm{~N}$ and up to 78 times higher for a sliding speed of $0.3 \mathrm{~m} / \mathrm{s}$ and applied load of $2 \mathrm{~N}$. 
(6) The wear mechanism of the hardened balls sliding against the hardened discs was adhesive-oxidative, while the wear mechanism of the $\mathrm{NbC}$ coated balls sliding against the hardened discs was abrasive-oxidative, with cracking of the niobium carbide layer.

\section{Acknowledgements}

This work has been supported by the State University of Santa Catarina (UDESC) and Federal Institute of Santa Catarina (IFSC).

\section{REFERENCES}

I Arai T, Harper S. Thermoreactive deposition/diffusion process. In: ASM International. Heat treating. I0th ed. Materials Park: ASM; 1991. 448 p. vol. 4.

2 Sen S. Influence of chromium carbide coating on tribological performance of steel. Materials \& Design. 2006;27(2):85-91.

3 Casteletti LC, Fernandes FAP, Heck SC, de Oliveira CKN, Lombardi-Neto A, Totten GE. Pack and salt bath diffusion treatments on steels. Heat Treatment Progress. 2009;9:49-52.

4 Fan XS, Yang ZG, Zhang C, Zhang YD, Che HQ. Evaluation of vanadium carbide coatings on AISI HI 3 obtained by thermo-reactive deposition/diffusion technique. Surface and Coatings Technology. 2010;205(2):64I-646.

5 Chen FS, Lee PY, Yeh MC. Thermal reactive deposition coating of chromium carbide on die steel in a fluidized bed furnace. Materials Chemistry and Physics. 1998;53:19-27.

6 King PC, Reynoldson RW, Brownrigg A, Long JM. Fluidized bed CrN coating formation on prenitrocarburized plain carbon steel. Journal of Materials Engineering and Performance. 2004;13(4):43।-438.

7 Sen U. Kinetics of niobium carbide coating produced on AISI 1040 steel by thermo-reactive deposition technique. Materials Chemistry and Physics. 2004;86(I):189-194.

8 Ozdemir O, Sen S, Sen U. Formation of chromium nitride layers on AISI I0IO steel by nitro-chromizing treatment. Vacuum. 2007;8I(5):567-570.

9 Tsipas SA, Omar H, Perez FH, Tsipas DN. Boroaluminide coatings on ferritic-martensitic steel deposited by low-temperature peck cementation. Surface and Coatings Technology. 2008;202(I4):3263-327I.

10 Sen S, Kocaman K. Structural properties and kinetics of nitro-niobized steels. Journal of Materials Science. 20II;46(24):7784-7792.

II Kilinc B, Sen U, Sen S. The properties of Cr-Al-N based coatings formed on AISI D2 steel by thermo-reactive diffusion technique. Acta Physica Polonica A. 2013;123(2):27I-273.

12 Gidikova N. Vanadium boride coatings on steel. Materials Science and Engineering A. 2000;278(2):18I-186.

I3 Samadi V, Habibolahzade A. Evaluation of microstructures and wear properties of duplex boride coatings. Materials Science and Technology. 20I0;26(I):4I-46.

14 Sustarsic B, Jenko M, Godec M, Kosec L. Microstructural investigation of NbC-doped vacuum-sintered tool-steelbased composites. Vacuum. 2003;7I(I):77-82.

15 Oliveira CKN, Muñoz Riofano RM, Casteletti LC. Micro-abrasive wear test of niobium carbide layers produced on AISI HI 3 and M2 steels. Surface and Coatings Technology. 2006;200(I6):5I40-5I 44.

16 Woydt M, Mohrbacher H. Friction and wear of binder-less niobium carbide. Wear. 20I3;306: I 26-I 30.

17 Sen S, Sen U. Sliding wear behavior of niobium carbide coated AISI 1040 steel. Wear. 2008;264(3):219-225.

18 Sen U. Wear properties of niobium carbide coatings performed by pack method on AISI I040 steel. Thin Solid Films. 2005;483(I): I52-I57.

19 Yoshida S. Recomendações para aumento da vida útil em moldes e ferramentas para fundição sob pressão de alumínio. In: Associação Brasileira de Metalurgia, Materiais e Mineração. Anais do $53^{\circ}$ Congresso Anual da ABM; 1997; São Paulo, Brasil. São Paulo: ABM; 1997.

20 Woydt M, Mohrbacher $\mathrm{H}$. The tribological and mechanical properties of niobium carbides $(\mathrm{NbC})$ bonded with cobalt for $\mathrm{Fe}_{3} \mathrm{Al}$. Wear. 20I4;32I(I): I-7.

2I Holmberg K. Coatings tribology: contact mechanisms and surface designs. Tribology International. 1998;3 I(I3): $107-120$.

22 Jiang J, Stott FH, Stack MM. The role of triboparticulates in dry sliding wear. Tribology International. 1998;3 I(5):245256. 
Krelling et al.

23 Kato K. Wear in relation to friction: a review. Wear. 2000;24I:I5I-I57.

24 Erdemir A, Bindal C, Pagan J, Wilbur P. Characterization of transfer layers on steel surfaces sliding against diamondlike hydrocarbon films in dry nitrogen. Surface and Coatings Technology. 1995;76-77:559-563.

25 Gaard A, Hallbäck N, Krakhmalev P, Bergström J. Temperature effects on adhesive wear in dry sliding contacts. Wear. 2010;268(7):968-975.

26 Cui XH, Wang SQ, Wei MX, Yang ZR. Wear characteristics and mechanisms of HI 3 steel with various tempered structures. Journal of Materials Engineering and Performance. 201 ;;20(6):1055-1062.

Received: 19 Apr. 2016

Accepted: 21 Sept. 2016 